\title{
Characterisation of parapoxviruses isolated from Norwegian semi-domesticated reindeer (Rangifer tarandus tarandus) Joern Klein ${ }^{1,2}$ and Morten Tryland*1,3
}

Address: ${ }^{1}$ Department of Microbiology and Virology, University of Troms $\varnothing$, Breivika, N-9037 Tromsø, Norway, ${ }^{2}$ Danish Institute for Food and Veterinary Research, Department of Virology, Lindholm, DK-4771 Kalvehave, Denmark and ${ }^{3 S}$ Section of Arctic Veterinary Medicine, Department of Food Safety and Infection Biology, The Norwegian School of Veterinary Science, PO Box 6204, N-9292 Tromsø, Norway

Email: Joern Klein - jkle@dfvf.dk; Morten Tryland* - morten.tryland@veths.no

* Corresponding author

Published: 05 September 2005

Virology Journal 2005, 2:79 doi:10.1186/1743-422X-2-79

This article is available from: http://www.virologyj.com/content/2/I/79

(C) 2005 Klein and Tryland; licensee BioMed Central Ltd.

This is an Open Access article distributed under the terms of the Creative Commons Attribution License (http://creativecommons.org/licenses/by/2.0), which permits unrestricted use, distribution, and reproduction in any medium, provided the original work is properly cited.
Received: 28 June 2005

Accepted: 05 September 2005

\begin{abstract}
Background: Two outbreaks of the disease contagious ecthyma were reported in 1999 and 2000 in Norwegian semi-domesticated reindeer (Rangifer tarandus tarandus). Contagious ecthyma is an epidermal disease of sheep and goats worldwide, which is caused by the zoonotic parapoxvirus orf virus. Characterisation of clinical samples from the two outbreaks in semi-domesticated reindeer in Norway by electron microscopy and PCR (B2L) revealed typical parapoxvirus particles and partial gene sequences corresponding to parapoxvirus, respectively. If contagious ecthyma in reindeer is caused by orf virus, the virus may be transferred from sheep and goats, via people, equipment and common use of pastures and corrals, to reindeer. Another possibility is that contagious ecthyma in reindeer is caused by a hitherto unclassified member of the parapoxvirus genus that circulates among reindeer herds and remains endemic in Norway.
\end{abstract}

Results: Genomic comparisons of one standard orf strain (orf NZ2) and the reindeer isolates, employing restriction fragment length polymorphism (RFLP) and random amplified polymorphic DNA (RAPD) analysis, demonstrated high similarity between the reindeer viruses and known orf virus strains. Partial DNA sequences of two different viral genes were determined for the different isolates and compared with corresponding parapoxvirus genebank sequences. The comparison/ alignment and construction of phylogenetic trees also point to an affiliation of the reindeer viruses to the species orf virus.

Conclusion: The results of this work imply that the parapoxvirus causing contagious ecthyma in Norwegian semi-domesticated reindeer belongs to the species orf virus and that the orf virus crosses the host species barrier from sheep and goat to semi-domesticated reindeer.

\section{Background}

Parapoxviruses (PPVs) (family Poxviridae) cause dermal diseases most commonly in sheep, goats and cattle [2], but also in semi-domesticated reindeer (Rangifer tarandus tarandus) [3] and wildlife, like seals [4], red deer [5] and squirrels [6]. The genus Parapoxvirus consists of five spe- cies and three tentative species [7]: Bovine popular stomatitis virus (BPSV), orf virus (ORFV), parapoxvirus of red deer in New Zealand (PVNZ), pseudocowpox virus (PCPV), and squirrel parapoxvirus (SPPV), as well as the tentative species of the genus: auzdyk disease virus, chamois contagious ecthyma virus and sealpox virus. 
The first documented outbreak of a contagious ecthymalike disease in Norwegian reindeer, took place in 1976 among experimental animals at the National Reindeer Research Station in Lødingen [8]. Also human parapoxvirus infections were associated with this outbreak [9]. In April 1999, the first outbreak in reindeer under regular herding conditions was reported in Troms County, followed by an outbreak one year later, also in April, in Nordland County. The outbreak in 2000 involved at least 30 out of 150 reindeer, which were corralled and supplementary fed during the winter. Seven of the infected animals died, due to massive oral cauliflower-like lesions and secondary bacterial infections [1].

In Norway, there are both wild and semi-domesticated reindeer. The latter is herded over an area of approximately $140.000 \mathrm{~km}^{2}$, which is about $40 \%$ of the mainland area of Norway. Most reindeer herding is conducted by the Saami people (indigenous people of Scandinavia), and the most dense reindeer herding area is in Finnmark county, Northern Norway, where the total number of animals is estimated to be around 140.000 animals (estimate for 2003 [10]). Semi-domesticated reindeer have seasonal migrations between winter (usually inland) and summer (usually coastal areas) pastures, and the pastures are organised in districts, reducing the contact between animals of different districts. However, sheep and goats also use the coastal pastures during spring, summer and autumn, and contact between different animal species is possible. Furthermore, it is not uncommon to use the same corrals and transport vehicles for reindeer and sheep, and remaining scabs from sheep with contagious ecthyma may as well be a source of infection for reindeer. Since the disease contagious ecthyma and orf virus is present among sheep and goats in most parts of the country, it is necessary to characterise the causative agent of contagious ecthyma in reindeer, in order to find out whether reindeer have their own parapoxvirus species, like red deer in New Zealand [5], or whether a transmission of virus between sheep and goats and reindeer is more likely.

Due to genetic heterogeneity within the genus, classification of PPV remains problematic and relies mostly on the source of the virus isolate; id est Parapoxviruses isolated from sheep will be classified as orf virus, virus isolated from cattle as pseudocowpox $[11,12]$. However, several molecular techniques have been used to characterise parapoxviruses. Inoshima et al. [13] reported a polymerase chain reaction (PCR) protocol assumed to be able to amplify all members of the parapoxvirus genus, based on primers from the B2L gene encoding a major envelope protein [14]. The gene region encoding a viral interleukin 10 orthologue (vIL-10) [15] has been used for characterisation, in combination with sequencing of the amplified
DNA products. Restriction fragment length polymorphism (RFLP) has also been used to compare parapoxvirus isolates $[5,16]$, and can be conducted both on genomic DNA as well as on smaller DNA fragments in combination with PCR. Also random amplified polymorphic DNA analysis (RAPD) may be used for characterisation purposes, as reported as a useful technique for comparing orthopoxviruses [17].

The aim of the present study was to characterise the causative agent of contagious ecthyma in semi-domesticated reindeer in Norway, and to compare this virus with other parapoxvirus isolates. This information is necessary to be able to sort out whether reindeer are exposed to orf virus, which is commonly affecting sheep and goats and also present among muskoxen in Norway, to bovine papillar stomatitis virus, which is present among cattle in Norway, or whether reindeer hosts a specific parapoxvirus species.

\section{Results \\ Restriction Fragment Length Polymorphism (RFLP) analysis}

RFLP patterns by the three restriction endonucleases, Hind III, Eco R1 and BAM H1 display identical DNA fragment patterns for orf virus and the parapoxvirus isolated from semi-domesticated Norwegian reindeer (Figure 1).

\section{Random Amplification of Polymorphic DNA (RAPD) analysis}

The RAPD patterns of the Finnish (Fi94.1Rt) and the Norwegian (N99.1Rt, N00.1Rt) reindeer isolates are similar to that of the orf viruses orf 11 and NZ2 and distinct to the sealpox and pseudocowpox patterns (Figure 2).

\section{Polymerase Chain Reaction (PCR)}

The vIL-10 PCR and GIF PCR were able to amplify DNA from all 25 isolates, whereas the B2L PCR did only amplify DNA from 17 isolates (Table 1 ).

\section{Phylogenetic analysis}

The Bayesian tree based on the the partial sequences of the B2L-gene (Figure 3) display species specific clustering of the parapoxvirus-genus.

Six clusters, representing the squirrel parapoxviruses, seal poxviruses, bovine papular stomatitis virus, pseudocowpoxviruses, parapoxvirus of red deer in New Zealand, and orf viruses were generated.

The Norwegian reindeer isolates clustered together with orf virus isolates from different host species and geographical origins. Also the Finnish reindeer isolates from 1992 and 1994 were in conjunction with the orf virus isolates, whereas more recent Finnish parapoxvirus isolates 
HindIII

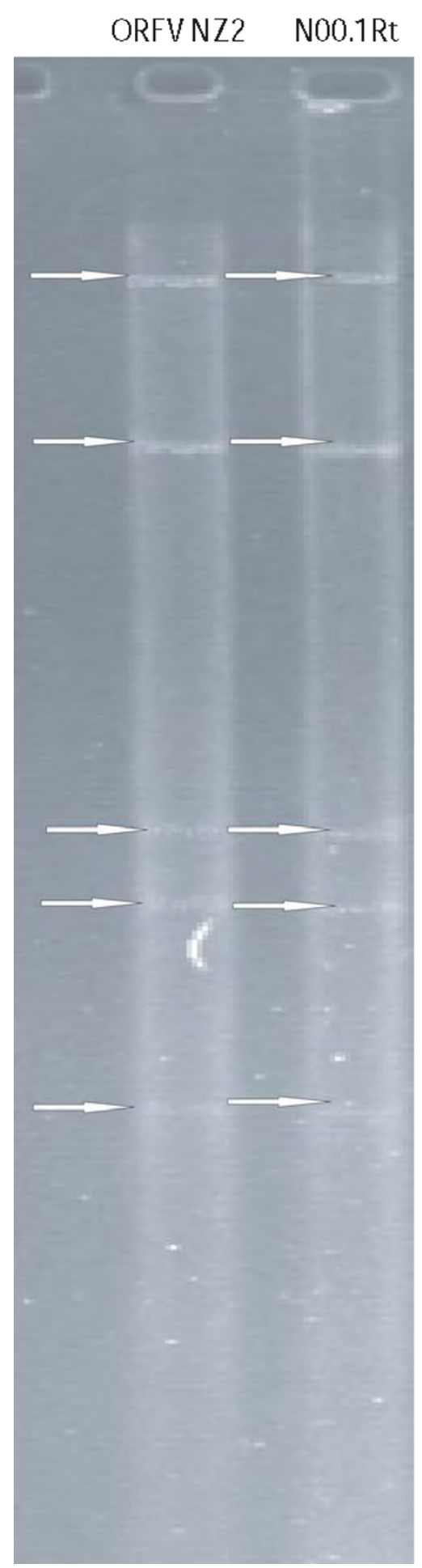

EcoR1

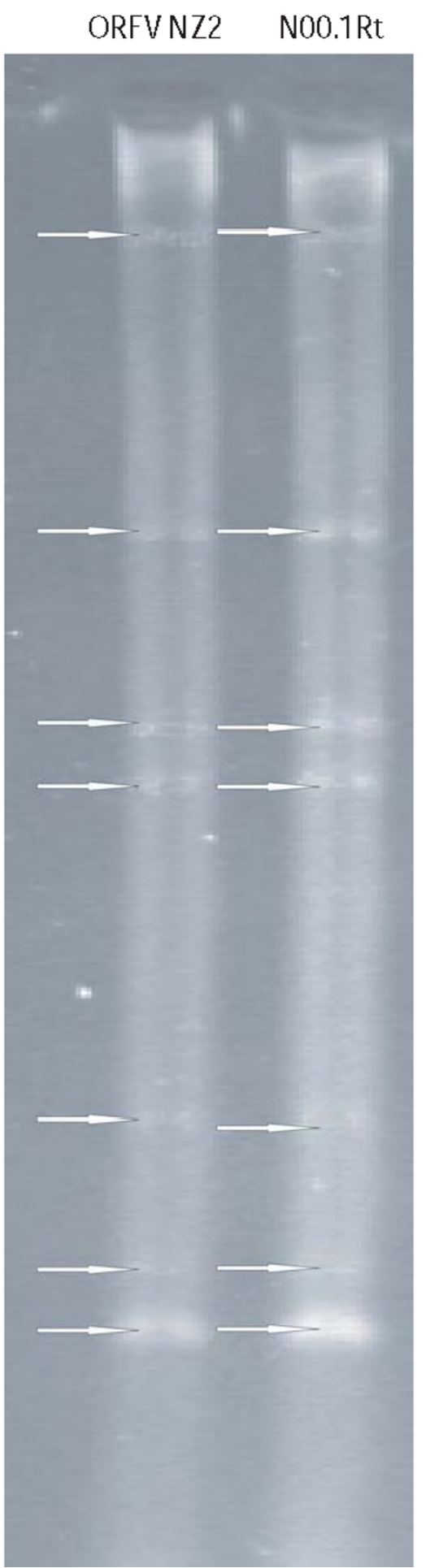

$\mathrm{BamH1}$

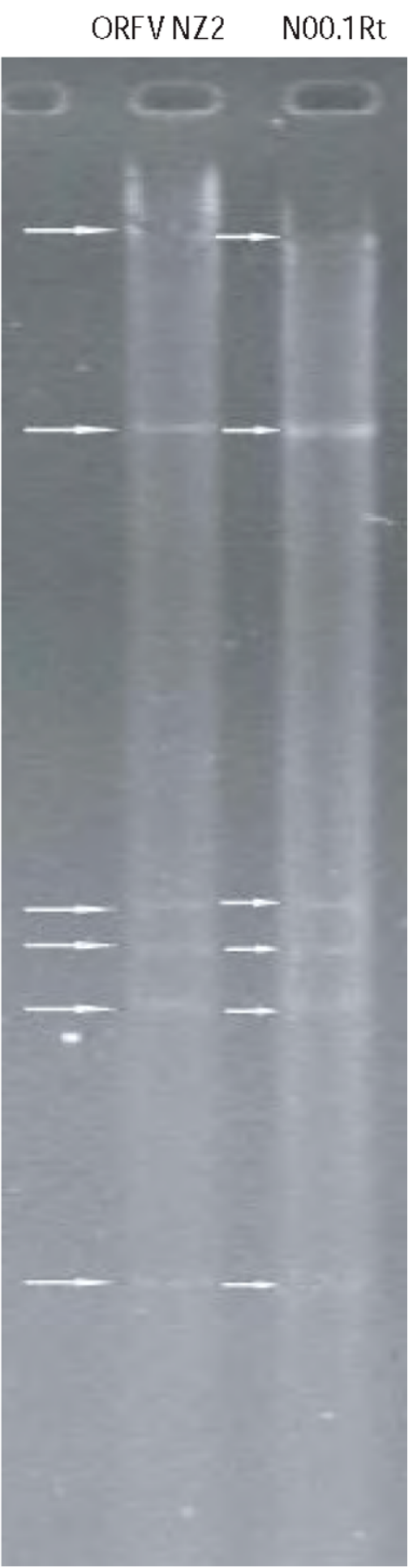

Figure I

Restriction fragment length polymorphism (RFLP) analysis of the standard orf virus strain NZ2 and the Norwegian reindeer isolate from Troms county 2000 (bands indicated by arrows) displays identical cleavage patterns for the two viruses. 


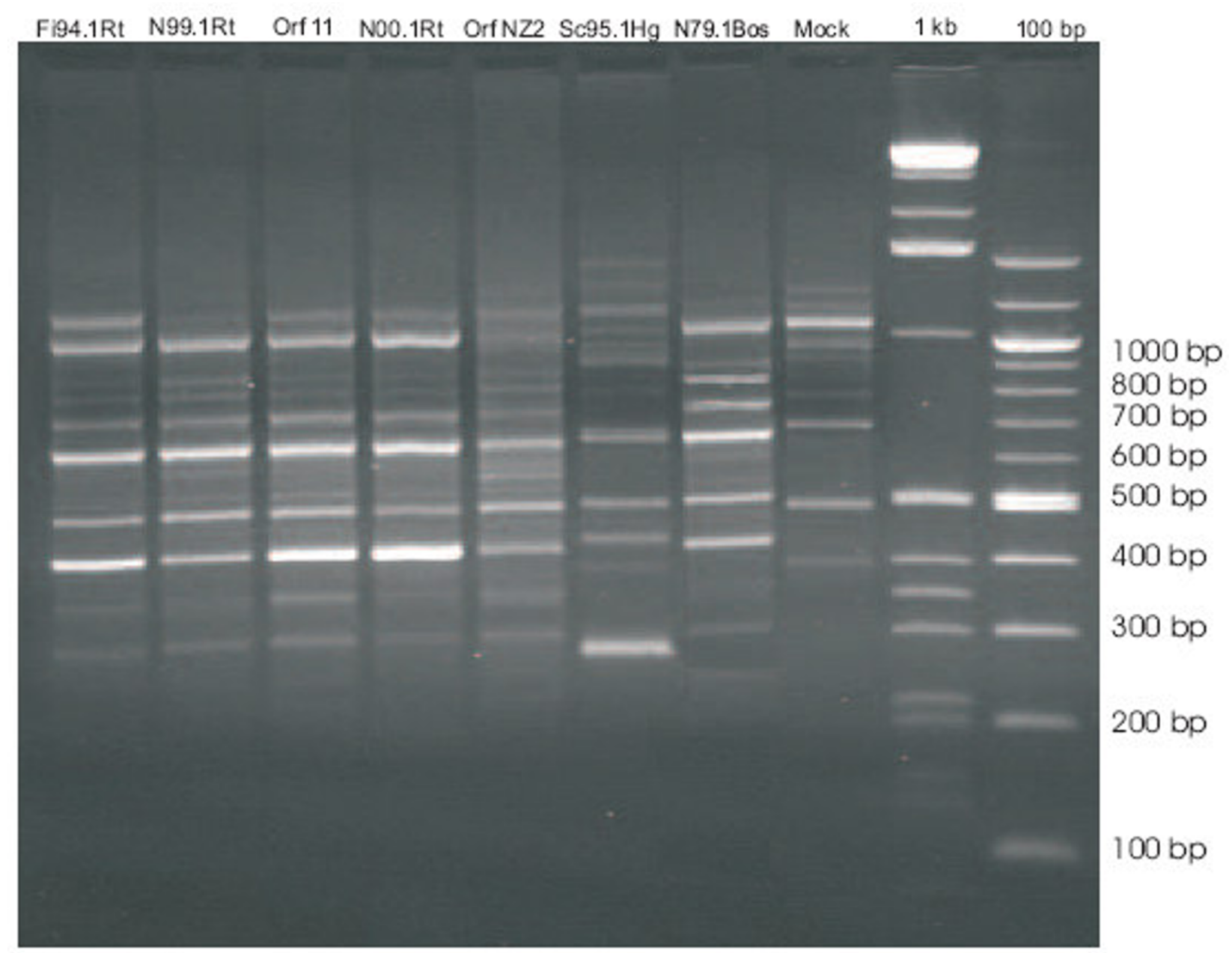

\section{Figure 2}

Random amplified polymorphic DNA (RAPD) analysis of different parapoxviruses. Lane I: reindeer Finland I994, Lane 2: reindeer Norway 1999, Lane 3: reference strain orf II, Lane 4: reindeer Norway 2000, Lane 5: orf virus NZ2, Lane 6: parapoxvirus from Weddell seal, Lane 7: parapoxvirus from cattle, Norway, Lane 8: mock infected cells, Lane 9 and 10: I kb and I00 bp ladder, respectively. Bands indicate similar patterns for orf and reindeer viruses, whereas parapoxvirus from seal and cattle are different.

causing contagious ecthyma in reindeer have been characterised as more related to pseudocowpoxviruses [18].

Phylogenetic analysis of interleukin 10 amino acid sequences from a range of mammalian species and the three translated viral interleukin 10 orthologue nucleotide sequences obtained from the two Norwegian (N00.1Rt and N99.1Rt) and one Finnish (Fi94.1Rt) virus isolates from semi-domesticated reindeer is shown in Figure 4 . The positions of the viral IL-10 indicate a high sim- ilarity to the corresponding genes (interleukin 10) of the main hosts of orf virus, goat and sheep. (Figure 4).

\section{Discussion}

Based on RFLP patterns obtained from the Norwegian reindeer isolates and orf NZ2, a close relationship between these viruses can be assumed (Figure 1). The RAPD patterns of the reindeer isolates and the standard orf virus strains orf 11 and orf NZ2 show high similarity in amplification patterns (Figure 2). This similarity is 
Table I: PCR and sequencing results obtained from parapoxvirus isolates of different species, reference orf virus strain (Orf II ) and an orf virus vaccine strain (NZ2). Successful amplification is indicated by Genebank accession number

\begin{tabular}{|c|c|c|c|c|c|}
\hline Signature & Host & Country of origin & B2L-PCR & vIL-I 0-PCR & GIF-PCR \\
\hline N99.IRt & Rangifer t. tarandus & Norway & AY605963 & AY605995 & AY605973 \\
\hline N00.IRt & Rangifer $t$. tarandus & Norway & AY605964 & AY605994 & AY605972 \\
\hline $\mathrm{N} 00.2 \mathrm{Rt}$ & Rangifer $t$. tarandus & Norway & AY605969 & AY606005 & AY 605985 \\
\hline N03.8Rt & Rangifer $t$. tarandus & Norway & AY605966 & AY605992 & AY606010 \\
\hline Fi94.IRt & Rangifer $t$. tarandus & Finland & AY605965 & AY605993 & AY60597I \\
\hline Fi92.IRt & Rangifer $t$. tarandus & Finland & AY605959 & AY60600I & AY605979 \\
\hline N79.IBos & Bos spec. & Norway & AY 605960 & AY60601I & AY605980 \\
\hline N92.IBos & Bos spec. & Norway & AY605961 & AY606002 & AY605981 \\
\hline N83.IBos & Bos spec. & Norway & AY605970 & AY606003 & AY605982 \\
\hline N85.IBos & Bos spec. & Norway & - & AY963707 & AY605984 \\
\hline N7I.IBos & Bos spec. & Norway & - & AY606012 & AY605983 \\
\hline $\mathrm{N} 02 . \mathrm{ICh}$ & Capra hircus & Norway & - & Not sequenced & AY606013 \\
\hline No0.ICh & Capra hircus & Norway & - & AY605999 & AY605977 \\
\hline N94.IOm & Ovibos moschatus & Norway & AY605962 & AY605996 & AY605974 \\
\hline N00.IOa & Ovis aries & Norway & AY605957 & AY605998 & AY605976 \\
\hline $\mathrm{N} 86.1 \mathrm{Oa}$ & Ovis aries & Norway & AY605968 & AY606007 & Not sequenced \\
\hline $\mathrm{N} 86.2 \mathrm{Oa}$ & Ovis aries & Norway & AY605967 & AY606008 & AY605990 \\
\hline N03.IOa & Ovis aries & Norway & - & AY963708 & AY605991 \\
\hline $\mathrm{Sc} 95.1 \mathrm{Hg}$ & Halichoerus grypus & Scotland & U49845AJ62290I & AY605997 & AY605975 \\
\hline N03.I Lw & Leptonychotes weddelli & Antarctica & A) 622900 & AY606015 & AY605989AY605989 \\
\hline Orf II & Cell culture & - & AY605958 & AY606000 & AY605978 \\
\hline Orf NZ2 & Vaccine & - & AY963706 & AY606006 & AY605988 \\
\hline
\end{tabular}

present in spite of the geographical distance between the Norwegian isolates and the orf strains originating from Great Britain and New Zealand.

Further, this work demonstrates that a virus species characterisation based on the nucleotide sequence of the PCRproduct from the B2L-PCR is possible. This characterisation method is easy to perform, because the PCR product is fast to obtain and to proceed.

The phylogenetic analysis of the partial B2L-gene sequence from the Norwegian reindeer isolates shows that these isolates can be allocated to the orf virus species. However, the clade credibility value of $37 \%$ also demonstrate a close relationship between the two different parapoxvirus species, orf and pseudocowpox virus.

Tikkanen et al. [18] demonstrated the affiliation of parapoxvirus isolates obtained from Finnish semi-domesticated reindeer during the early outbreaks (1992-1994) in Finland, to the orf virus species and from later outbreaks to the pseudocowpox viruses, which is congruent with our results.

The close clustering of the translated sequences obtained from virus isolated from reindeer (two Norwegian; 1999, 2000, and one Finnish; 1994) with the amino acid sequences of sheep and goat interleukin 10 demonstrate a high relationship of the parapoxvirus isolated from reindeer to the main hosts of orf virus (sheep and goat). It seems that the viral interleukin 10 orthologue of the reindeer isolates is highly adapted to the immune system of sheep and goats, which also indicates that the reindeer parapoxvirus belongs to the orf virus species.

Our results indicate that neither geographical distance, nor crossing the host barrier from sheep or goat to semidomesticated reindeer did affect the characteristics of the parapoxvirus orf virus investigated in this study.

The B2L PCR has previously been described as a tool to amplify all species within the parapoxvirus genus [13]. However, we were not able to amplify B2L sequences from nine of the twenty-five isolates included in our study. Many members of the subfamily chordopoxvirinae show genetic rearrangement at the terminal sequences of the genome, which is thought to be an evolutionary mechanism, allowing the virus to adapt to changes of the immune response of the host [19]. Parapoxvirus replicated in vitro show rearrangement of the left terminal end of the viral genome, resulting in the deletion of three genes (E2L, E3L, G1L) and $80 \%$ of a fourth one, the G2L [20-22]. All these four genes play a major role in virulence and host specificity [23]. The B2L gene is localised beside the left terminal end of the genome, so that heterogeneity in the primer binding regions or complete deletion of the 


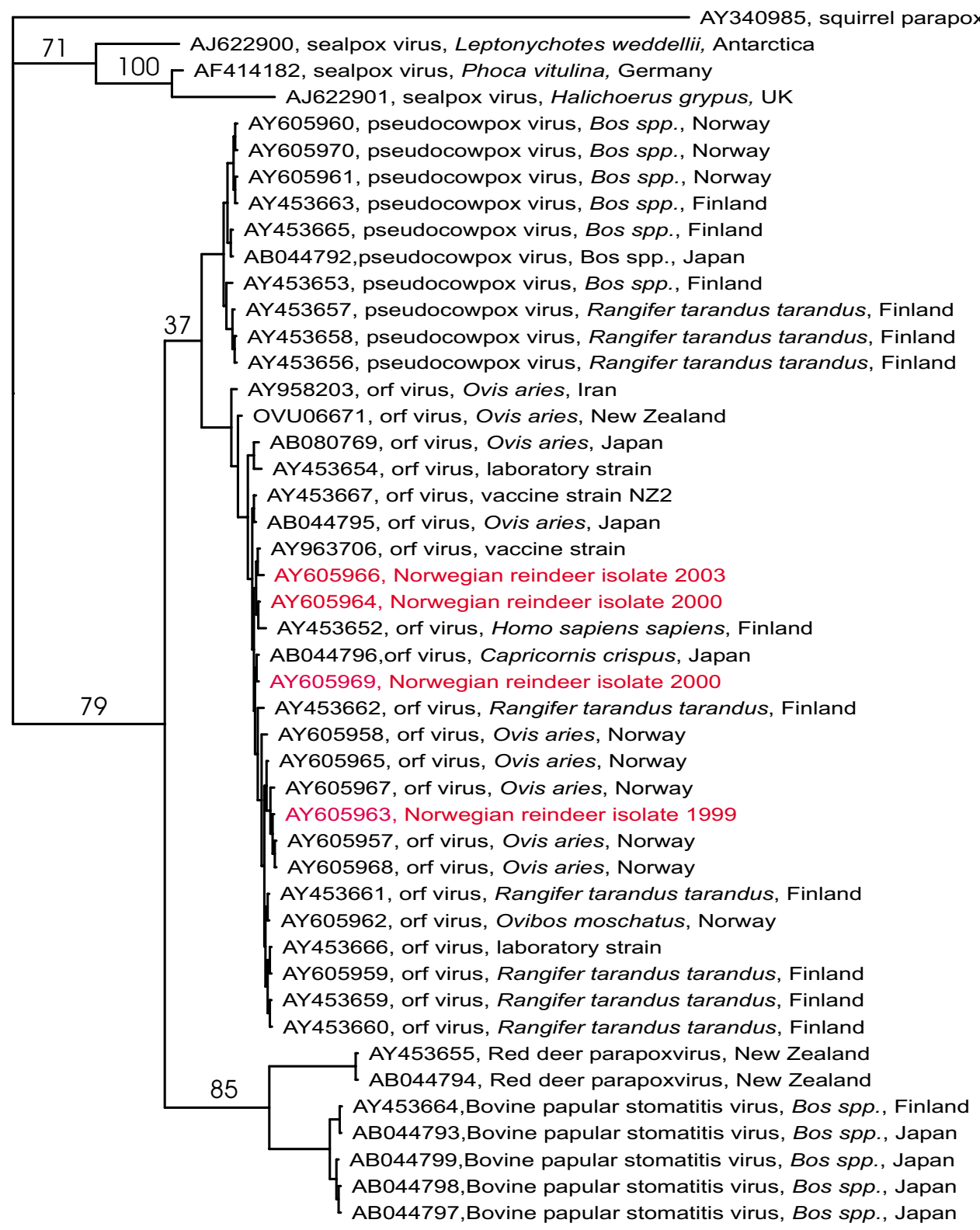

\section{Figure 3}

Bayesian tree based on the partial nucleotide sequences of the B2L gene ( $379 \mathrm{nt})$ obtained in this study compared with corresponding DNA sequences from parapoxviruses published in Genebank. Isolates are described by Genebank accession number, parapoxvirus species, source and country of origin. Numbers at major clades indicate clade credibility values in Percent.

B2L gene, through the same rearrangement mechanisms as in the left terminal region itself, can be the reason for the negative results of the B2L-PCR. However, further analyses are needed to evaluate this hypothesis. As compared to the results of the B2L-PCR, the GIF PCR seems to be more sensitive for different members of the genus and 


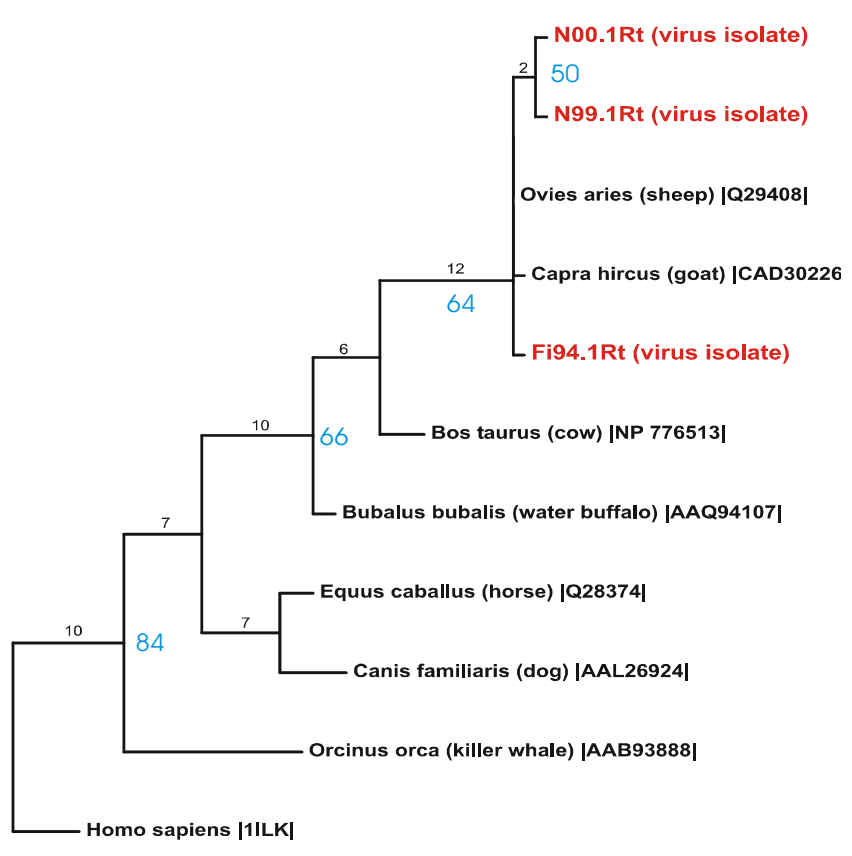

\section{Figure 4}

Maximum Parsimony tree based on the translated nucleotide sequences of the Norwegian and Finnish reindeer vlL- 10 gene amplicons obtained in this study, compared with corresponding amino acid sequences from mammals published in Genebank. Black numbers (branch length) describe the genetic distance/number of changes along the branch. Blue numbers (bootstrap values) describe the reliability for each clade in percent.

can be used for rapid genus-identification. However, the GIF gene is localised in the right terminal gene region [24] and may also undergo genetic rearrangements due to adaptation processes. The GIF gene has so far only been detected in parapoxviruses [23].

The vIL-10-PCR amplified all tested isolates, but rearrangements of the vIL-10 gene have also been demonstrated, in terms of duplications in the inverted terminal repeat [25]. Thus, genetic rearrangements may be a problem when designing a PCR that are supposed to detect parapoxviruses in general. The use of a multiplex PCR, with a combination of one or more of the gene targets desribed above, may thus be a solution to this problem.

\section{Conclusion}

The results of this work point out that the parapoxvirus that has caused contagious ecthyma in Norwegian semidomesticated reindeer belongs to the orf virus species, and it is to assume that the orf virus crosses the host species barrier from sheep and goat to semi-domesticated reindeer.

Sheep and goats in Norway are commonly free-ranging during the snow-free period, sharing pastures with semidomesticated reindeer. During seasonal migrations and corralling of animals for slaughter etc. they may also share fences, transport vehicles and other equipment.

As far as we know, contagious ecthyma is the single disease that has caused the most serious economical losses for reindeer herders in the Nordic countries in recent times, and especially so in Finland. Consequently, the common use of equipment, pastures, transport vehicles and facilities for semi-domesticated reindeer, sheep and goats should be avoided, to prevent cross infections.

The outcome of parapoxvirus infections in reindeer seems to be dependent on many environmental factors in addition to the exposure to the virus. Certain types of stress is believed to play a key role, and such stress factors may be lack of food, as well as handling, corralling and transport of animals [3,1]. A changing trend in reindeer herding conditions, facing higher animal densities, faster movements of animals using helicopter and snow mobiles, increased use of supplemental feeding and corralling of animals, and increased transport distances to slaughterhouse may represent factors that can predispose for contagious ecthyma as well as other diseases in reindeer.

\section{Methods \\ Viruses}

An overview of the virus isolates included in this study is given in Table 1. Viruses were purified by metrizamide gradient centrifugation from homogenised scab material obtained from Norwegian semi-domesticated reindeer (N99.1Rt, N00.2Rt, N03.8Rt), Finnish semi-domesticated reindeer (Fi94.1Rt, Fi92.1Rt), Norwegian cattle (N79.1Bos, N92.1Bos, N83.1Bos, N71.1Bos, N85.1Bos), Norwegian goat (N02.1Ch, N00.1Ch), Norwegian musk ox (Ovibos moschatus) (N94.1Om, N86.1Om), Norwegian sheep (N00.1Oa, N86.1Oa, N86.2Oa, N03.1Oa, N03.2Oa, N00.2Oa), Scottish grey seal (Halichoerus grypus) (Sc95.1Hg) and Antarctic Weddell seal (Leptonychotes weddellii) (N03.1Lw) as described previously [26].

The orf virus strain orf 11 was provided by the Moredun Research institute (Great Britain) and the orf virus strain NZ2 was derived from a non-attenuated commercial vaccine against contagious ecthyma in sheep (Scabivax ${ }^{\circledR}$, Shering-Plough A/S Animal Health, Norway). 


\section{Cell culture}

Orf viruses NZ2 and orf 11 and the parapoxviruses isolated from Norwegian semi-domesticated reindeer (N00.1Rt, N99.1Rt), Finnish semi-domesticated reindeer (Fi94.1Rt) and the Scottish grey seal (Sc95.1Hg) were propagated in Madine-Darby bovine kidney (MDBK; DSMZ No; ACC 174) cells, which are permissive for parapoxviruses [27]. Cells were cultivated in Dulbecco's MEM supplemented with $5 \%$ Fetal Bovine Serum and Penicillin (100 $\mu \mathrm{g} / \mathrm{ml}) /$ Streptomycin-solution (100 IU/ml) and incubated at $37^{\circ} \mathrm{C}$ with $5 \% \mathrm{CO}_{2}$.

\section{DNA extraction}

For the purpose of RFLP and RAPD analysis, viral DNA was extracted from the cytoplasma of infected cells, using reducing, non-ionic and proteolytic detergents, as described in detail by Esposito et al. [28].

For PCR, viral DNA was extracted using QIAamp ${ }^{\circledR}$ DNA Mini Kit (QIAGEN, Hilden, Germany).

\section{RFLP}

Viral DNA was digested for 4 hours with the restriction enzymes HindIII, EcoRI and BamHI (NEW ENGLAND BioLabs ${ }^{\circledast}$ Inc., UK). DNA fragments were separated on a $0.6 \%$ agarose gels for 20 hours at $0,6 \mathrm{~V} / \mathrm{cm}$.

\section{RAPD}

RAPD were conducted with the commercial kit Ready.To.Go ${ }^{\circledast}$ RAPD Analysis Beads (Amersham Biosciences AB, Uppsala, Sweden). Five $\mu$ l of the RAPD analysis primer no. 6 (5'- CCCGTCAGCA-3') were added to 19 $\mu \mathrm{l}$ of $\mathrm{dH} 2 \mathrm{O}$ and $1 \mu \mathrm{l}$ of template DNA and gently mixed. The following low stringency cycling profile was used: initial denaturation at $95^{\circ} \mathrm{C}$ for $4 \mathrm{~min}$, followed by 45 cycles consisting of denaturation at $95^{\circ} \mathrm{C}$ for $1 \mathrm{~min}$, annealing at $36^{\circ} \mathrm{C}$ for $1 \mathrm{~min}$, and elongation at $72^{\circ} \mathrm{C}$ for $2 \mathrm{~min}$. DNA fragments were separated on a $2 \%$ agarose gel at $7,5 \mathrm{~V} / \mathrm{cm}$ for 2,5 hours.

\section{PCR}

Three different PCR protocols were performed as specified below:

\section{B2L-PCR}

Inoshima et.al. [13] describe a PCR specific for the detection of all parapoxviruses, resulting in the amplification of theoretically a 594 bp product. The primers (PPP 1 and PPP 4) are based on the B2L gene sequence of the orf virus strain NZ2. The B2L gene encode a homologue of the vaccinia virus major envelope antigen p37K gene [29]. PCR was carried out as described by Inoshima et al. [16] with the exception that $5 \%$ dimethylsulfoxide (DMSO) was added to the reaction mix as a PCR enhancer.

\section{GIF-PCR}

The Granulocyte-macrophage-colony-stimulating factor (GM-CSF) and Interleukin-2 inhibition factor (GIF) is found only in parapoxviruses, and represents an important virulence factor [24]. Amplification of parts of the GIF gene may thus be useful, both for detection of parapoxvirus DNA in tissue samples and for virus species differentiation. The GIF PCR primers (GIF $5 \rightarrow 5$ '-gct cta gga aag atg gcg tg-3' GIF $6 \rightarrow$ 5'-gta ctc ctg gct gaa gag cg -3'), generating amplicons of approximately $408 \mathrm{bp}$, were obtained from the published sequence of the orf virus GIF gene (Genebank accession number AF192803.1; Deane et al., 2000) and selected by the online tool "GeneFisher" [30].

Five $\mu$ l template DNA were added to $45 \mu \mathrm{l}$ of the PCR reaction mixture containing $0.2 \mathrm{mM}$ primers (GIF 5 and GIF 6), $200 \mathrm{mM}$ each of dATP, dCTP, dGTP and dTTP, $10 \mathrm{mM}$ Tris- $\mathrm{HCl}$ (pH 8.3), $50 \mathrm{mM} \mathrm{KCl}, 1.5 \mathrm{mM} \mathrm{MgCl}_{2}$ and $1 \mathrm{U}$ of AmpliTaq $^{\circledast}$ Gold DNA polymerase (Applied Biosystems, Norway). DNA was amplified with a DNA Thermal Cycler PE9700 (Perkin Elmer) by a two-step cycling reaction as follows: $95^{\circ} \mathrm{C}$ for $15 \mathrm{~min}$, and five cycles of $94^{\circ} \mathrm{C}$ for 30 sec, $57^{\circ} \mathrm{C}$ for $2 \mathrm{~min}$ and $72^{\circ} \mathrm{C}$ for $30 \mathrm{sec}$, and then 35 cycles of $94^{\circ} \mathrm{C}$ for $30 \mathrm{sec}, 57^{\circ} \mathrm{C}$ for $30 \mathrm{sec}$ and $72^{\circ} \mathrm{C}$ for 30 $\mathrm{sec}$, followed by a final extension step of $72^{\circ} \mathrm{C}$ for $10 \mathrm{~min}$. The resulting PCR product was examined by electrophoresis, using a 1,2 \% agarose gel, containing $0,005 \%$ ethidium bromide, with a separation time of 1,5 hours at $6,5 \mathrm{~V} / \mathrm{cm}$.

\section{vIL-IO PCR}

The viral interleukin 10 orthologue [15] need to have a close similarity to the IL-10 of the host for effective virus propagation. PCR targeting this gene may be useful for genus affiliation, and nucleotide sequencing of the PCR amplicon followed by virtual translation to the protein sequence may be suitable for virus characterisation.

Primers (vIL-10-3 $\rightarrow$ 5'-atg cta ctc aca cag tcg ctc c-3', vIL$10-4 \rightarrow 5$ '-tat gtc gaa ctc gct cat ggc c-3') were obtained from consensus sequences previously reported to Genebank (accession numbers OVU82239; [31], OVU60552; [32], AY231116.1; [33], AY186733.1; [34], AY186732; [34]) and selected by the online tool "GeneFisher[30]. The expected length of the resulting amplicon is approximately $300 \mathrm{bp}$. The reaction mixture, cycling profile and agarose gel analysis was conducted as described for the GIF PCR.

\section{Nucleotide sequencing}

The resulting amplicons of the B2L, GIF and vIL-10 PCR were prepared for nucleotide sequencing by enzymatic removal of unused dNTP and primers (ExoSAP-IT ${ }^{\mathrm{Tm}}$; Amersham Pharmacia Biotech, Sweden). The enzyme 
preparation $\left(0,5 \mu \mathrm{l}\right.$; ExoSAP-IT $\left.{ }^{\mathrm{TM}}\right)$ was added directly to $6,5 \mu \mathrm{l}$ of the PCR product and incubated at $37^{\circ} \mathrm{C}$ for 1 hour. ExoSAP-IT ${ }^{\mathrm{TM}}$ was inactivated by heating to $80^{\circ} \mathrm{C}$ for 15 minutes. After the clean-up procedure the sequencing protocol for the BigDye ${ }^{\circledR}$ Terminator v3.1 cycle sequencing kit (Applied Biosystems, Norway) was performed. Seven $\mu \mathrm{l}$ of the purified PCR product was mixed with $4 \mu \mathrm{l}$ "Ready Reaction Premix", $2 \mu$ l sequencing-buffer, 3,2 $\mu \mathrm{l}$ of $20 \mu \mathrm{M}$ Primer solution, $1 \mu \mathrm{l} \mathrm{DMSO}$ and $2,8 \mu \mathrm{l} \mathrm{dH} 2 \mathrm{O}$. This mixture was thermal cycled 25 times at $96^{\circ} \mathrm{C}$ for 10 seconds, $50^{\circ} \mathrm{C}$ for 5 seconds and $60^{\circ} \mathrm{C}$ for 4 minutes. DNA was precipitated with ethanol and the sequence was determined with the "ABI PRISM 377 Genetic Analyser" (Applied Biosystems, Norway).

\section{Phylogenetic analysis}

Multiple sequence alignment of the 379 nucleotide long partial B2L-sequence was conducted using CLUSTAL X (version 1.81; [35]) and phylogenetic analysis was performed by Bayesian Analysis using MrBayes [36] with the following settings. The maximum likelihood model employed 2 substitution types ("nst $=2$ "), with base frequencies set to the empirically observed values ("basefreq = empirical"). Rate variation across sites was modelled using a gamma distribution (rates="gamma"). The Markov chain Monte Carlo search was run with 4 chains for 500000 generations, with trees begin sampled every 100 generations (the first 1000 trees were discarded as "burnin").

\section{Competing interests}

The author(s) declare that they have no competing interests.

\section{Authors' contributions}

This work is based on the MPhil thesis of Jörn Klein. Morten Tryland was the main supervisor of this thesis and project leader. The thesis is available online under: http:/ uit.no/getfile.php?PageId=647\&FileId=26

\section{Acknowledgements}

Hilde Hansen is greatly acknowledged for her contribution to this characterisation study. The contributors of parapoxvirus isolates are also greatly acknowledged: Antti Oksanen (Finnish reindeer isolates), Johan Krogsrud (isolates from cattle), Terje Josefsen, Karen Sørensen and Torill Mørk (isolates from sheep and goats), Arnoldus S. Blix (isolates from musk oxen), Colin Mclnnes (orf II isolate), and Peter Nettleton (grey seal isolate). This work was supported financially by the Reindeer Husbandry Development Fund, 2002-2004.

\section{References}

I. Tryland M, Josefsen $T$, Oksanen A, Aschfalk A: Contagious ecthyma in Norwegian semi-domesticated reindeer (Rangifer tarandus tarandus). Vet Rec 200I, 149:394-395.

2. Kuhl JT, Huerter CJ, Hashish H: A case of human orf contracted from a deer. Cutis 2003, 7 I (4):288-290.

3. Oksanen A, Norberg H: Smittsom munnskurv. Reindriftsnytt 1994 , 3-4:13-17.
4. Tryland M, Klein J, Nordoy ES, Blix AS: Isolation and partial characterization of a parapoxvirus isolated from a skin lesion of a Weddell seal. Virus Res 2005, I 08(I-2):83-87.

5. Robinson AJ, Mercer AA: Parapoxvirus of red deer: evidence for its inclusion as a new member in the genus Parapoxvirus. Virology 1995, 208:8|2-8I5.

6. Thomas K, Tompkins DM, Sainsbury AW, Wood AR, Dalziel R, Nettleton PF, Mclnnes CJ: A novel poxvirus lethal to red squirrels (Sciurus vulgaris). J Gen Virol 2003, 84:3337-334I.

7. Büchen-Osmond C, Editor: ICTVdb Index of Viruses: Catalogue of virus taxonomy and nomenclature approved by the International Committee on Taxonomy of Viruses [http://www.ncbi.nlm.nih.gov/lCTVdb/lctv/frindex.htm]. Internet, cited 2003 May 16

8. Kummeneje K, Krogsrud J: Contagious ecthyma (orf) in reindeer (Rangifer $t$. tarandus). Vet Rec 1979, 105(3):60-61.

9. Falk ES: Parapoxvirus infections of reindeer and musk ox associated with unusual human infections. $\mathrm{Br} J$ Dermatol 1978 , 99(6):647-54.

10. Hætta Jl, editor: Reindriftsnytt. 1978.

II. Robinson AJ, Ellis G, Balassu T: The genome of orf virus: restriction endonuclease analysis of viral DNA isolated from lesions of orf in sheep. Arch Virol 1982, 7 I (1):43-55.

12. Büttner M, Rziha H-J: Parapoxviruses: From the Lesion to the Viral Genome. J Vet Med B 2002, 49:7-16.

13. Inoshima $Y$, Morooka A, Hiroshi S: Detection and diagnosis of parapoxvirus by the polymerase chain reaction. J Virol Methods 2000, 84:20I-208.

14. Sullivan J, Fraser K, Fleming S, Robinson A, Mercer A: Sequence and transcriptional analysis of an orf virus gene encoding ankyrin-like repeat sequences. Virus Genes 1994, 9:277-282.

15. Haig D, Flemming S: Immunomodulation by virulence proteins of the Parapoxvirus orf virus. Vet Immunol Immunopathol 1999 , 72:8I-86.

16. Inoshima Y, Murakami K, Yokoyama T, Sentsui H: Genetic heterogeneity among parapoxviruses isolated from sheep, cattle and Japanese serows (Capricornis crispus). J Gen Virol 200I, 82: $1215-1220$.

17. Stemmler M, Neubauer $\mathrm{H}$, Meyer $\mathrm{H}$ : Comparison of closely related orthopoxvirus isolates by random amplified polymorphic DNA and restriction fragment length polymorphism analysis. J Vet Med B Infect Dis Vet Public Health 200I, 48(9):647-54.

18. Tikkanen MK, McInnes CJ, Mercer AA, Buttner M, Tuimala J, HirvelaKoski V, Neuvonen E, Huovilainen A: Recent isolates of parapoxvirus of Finnish reindeer (Rangifer tarandus tarandus) are closely related to bovine pseudocowpox virus. J Gen Virol 2004 , 85: $|4| 3-14 \mid 8$.

19. Turner PC, Moyer RW: The molecular pathogenesis of poxviruses. Curr Top Microbiol Immunol 2004, I63: I25- I5I.

20. Fleming S, Lyttle D, Sullivan J, Mercer A, Robinson A: Genomic analysis of a transposition-deletion variant of orf virus reveals a $3.3 \mathrm{kbp}$ region of non-essential DNA. J Gen Virol 2004, 76:2969-2978.

21. Cottone R, Büttner M, Bauer B, Henkel M, Hettich E, Rziha H-J: Analysis of genomic rearrangement and subsequent gene deletion of attenuated Orf virus strain DI70I. Virus Res 1998 56:53-67.

22. Mclnnes C, Wood A, Nettleton P, Gilray J: Genomic Comparsion of an Avirulent Strain of Orf Virus with that of a Virulent Wild Type Isolate Reveals that the Orf Virus Gene G2L is Non-Essential for Replication. Virus Genes 200I, 22: I4I-I 50.

23. Haig $D$, Mclnnes $C$ : Immunity and counter-immunity during infection with the Parapoxvirus orf virus. Virus Res 2002, 88:3-16.

24. Deane D, Mclnnes C, Percival A, Wood A, Thomson J, Lear A, Gilray J, Fleming $S$, Mercer A, Haig D: Orf virus encodes a novel secreted protein inhibitor of granulocyte-macrophage colony-stimulating factor and interleukin-2. I Virol 2000, 74(3): $1313-1320$

25. Rzhia H, Henkel M, Cottone R, Meyer M, Dehio C, Büttner M: Parapoxviruses: potential alternative vectors for directing the immune response in permissive and non-permissive hosts. Biotechnol 1999, 83:137-145.

26. Tryland M, Sandvik T, Hansen H, Haukenes G, Holtet L, Bennett M, Mehl R, Moens U, Olsvik O, Traavik T: Characteristics of four 
cowpox virus isolates from Norway and Sweden. APMIS 1998 , 106(6):623-635

27. Kruse N, Weber O: Selective induction of apoptosis in antigenpresenting cells in mice by Parapoxvirus ovis. J Virol 200I, 75(10):4699-4704.

28. Esposito J, Condit R, Obijeski J: The preparation of orthopoxvirus DNA. J Virol Methods I98I, 2(3): 175-179.

29. Sullivan J, Mercer A, Fleming S, Robinson A: Identification and Characterisation of an Orf virus Homologue of the Vaccina Virus Gene Encoding the Major Envelope Antigen p37K. Virology 1994, 202:968-973.

30. Schleiermacher C, Meyer F: GeneFisher. 2003 [http://www.tech fak.uni-bielefeld.de/ags/pi/GeneFisher/]. April 2004

31. Fleming SB, McCaughan CA, Andrews AE, Nash AD, Mercer A: A homolog of interleukin- 10 is encoded by the poxvirus orf virus. J Virol 1997, 71:4857-4861.

32. Fleming B, McCaughan CA, Andrews AE, Nash AD, Mercer AA: A homolog of interleukin- 10 is encoded by the poxvirus orf virus. Journal of Virology 1997, $71: 4857-4861$.

33. Mclnnes C, Wood A: A preliminary transcript map of the early genes of orf virus. Unpublished 2003.

34. Rziha HJ, Bauer B, Adam KH, Rottgen M, Cottone R, Henkel M, Dehio $C$, Büttner M: Relatedness and heterogeneity at the near-terminal end of the genome of a Parapoxvirus bovis I strain (B I77) compared with Parapoxvirus ovis (Orf virus). J Gen Virol 2003, 84: I I I-I I I6.

35. Thompson J, Gibson T, Plewniak F, Jeanmougin F, Higgins D: The ClustalX windows interface: flexible strategies for multiple sequence alignment aided by quality analysis tools. Nucleic Acids Research 1997, 24:4876-4882.

36. Huelsenbeck J, Ronquist F: MRBAYES: Bayesian inference of phylogeny. Bioinformatics 200I, 17:754-755.

Publish with BioMed Central and every scientist can read your work free of charge

"BioMed Central will be the most significant development for disseminating the results of biomedical research in our lifetime. "

Sir Paul Nurse, Cancer Research UK

Your research papers will be:

- available free of charge to the entire biomedical community

- peer reviewed and published immediately upon acceptance

- cited in PubMed and archived on PubMed Central

- yours - you keep the copyright 